\title{
Metabolic diversity and niche structure in sponges from the Miskito Cays, Honduras
}

Christopher J Freeman, Cole G Easson, David M Baker

Hosting symbionts provides many eukaryotes with access to the products of microbial metabolism that are crucial for host performance. On tropical coral reefs, many (High Microbial Abundance [HMA]), but not all (Low Microbial Abundance [LMA]) marine sponges host abundant symbiont communities. Although recent research has revealed substantial variation in these sponge-microbe associations (termed holobionts), little is known about the ecological implications of this diversity. We investigated the expansion of diverse sponge species across isotopic niche space by calculating niche size (as standard ellipse area $\left[\mathrm{SEA}_{\mathrm{c}}\right]$ ) and assessing the relative placement of common sponge species in bivariate $\left(\delta^{13} \mathrm{C}\right.$ and $\left.\delta^{15} \mathrm{~N}\right)$ plots. Sponges for this study were collected from the relatively isolated reefs within the Miskito Cays of Honduras. These reefs support diverse communities of HMA and LMA species that together span a gradient of photosymbiont abundance, as revealed by chlorophyll a analysis. HMA sponges occupied unique niche space compared to LMA species, but the placement of some HMA sponges was driven by photosymbiont abundance. In addition, photosymbiont abundance explained a significant portion of the variation in isotope values, suggesting that access to autotrophic metabolism provided by photosymbionts is an important predictor in the location of species within isotopic space. Host identity accounted for over $70 \%$ of the variation in isotope values within the Miskito Cays and there was substantial variation in the placement of individual species within isotopic niche space, suggesting that holobiont metabolic diversity may allow taxonomically diverse sponge species to utilize unique sources of nutrients within a reef system. This study provides initial evidence that microbial symbionts allow sponges to expand into novel physiochemical niche space. This expansion may reduce competitive interactions within coral reefs and promote diversification of these communities. 
1 Metabolic diversity and niche structure in sponges from the Miskito Cays, Honduras

2 Christopher J. Freeman ${ }^{1 *}$, Cole G. Easson ${ }^{2}$, and David M. Baker ${ }^{3}$

$3 \quad{ }^{1}$ Smithsonian Marine Station, Fort Pierce, Florida, USA

$4{ }^{2}$ Department of Biology, University of Alabama at Birmingham, Birmingham, Alabama, USA

$5{ }^{3}$ School of Biological Sciences and Swire Institute of Marine Science, University of Hong Kong, 6 Hong Kong, PRC

7 *Corresponding author is Christopher Freeman: email: freemanc@si.edu, Tel No. 772-462-0989, 8 Smithsonian Marine Station, 701 Seaway Drive, Fort Pierce, Florida 34949

\section{Introduction} By expanding the metabolic repertoires of foundational species, symbiotic interactions

11 represent important processes underlying some of the most biodiverse ecosystems worldwide 


\section{PeerJ Reviewing Manuscript}

12 (Moya et al., 2008; Vrijenhoek, 2010). This is exemplified on oligotrophic coral reefs, where

13 autotrophic metabolism of microbial symbionts supplements heterotrophic feeding of reef-

14 building corals (Muscatine \& Cernichiari, 1969; Boucher, James \& Keeler, 1982; Muscatine,

15 Porter \& Kaplan, 1989; Baker et al., 2013). Interestingly, although it is well established that

16 severe nutrient limitation has favored the evolution of these and other host-symbiont units

17 (termed holobionts; Rosenberg et al., 2007; Zilber-Rosenberg \& Rosenberg, 2008), it is becoming

18 increasingly apparent that evolution has also led to diversification in these interactions across

19 functional groups and host species (Thacker \& Freeman, 2012; DM. Baker, unpublished data).

20 For instance, while some sponge hosts support abundant and diverse symbiont

21 communities (termed High Microbial Abundance [HMA]), other sympatric sponge species only

22 host sparse symbiont communities (termed Low Microbial Abundance [LMA] (Webster et al.,

23 2010; Schmitt et al., 2012; Thacker \& Freeman, 2012; Gloeckner et al., 2014). By hosting

24 autotrophic symbionts, many of these HMA species are able to assimilate both inorganic and

25 organic sources of C and N, whereas LMA sponges may be restricted to feeding heterotrophically

26 on specific portions of the particulate organic matter (POM) pool in the water column (Thurber,

27 2007; Taylor et al., 2007; Maldonado, Ribes \& van Duyl, 2012; Thacker \& Freeman, 2012). The

28 placement of sponges into one of these putative guilds is widespread, but symbiont metabolism is

29 also highly variable across different HMA species, making such broad generalizations difficult.

30 For instance, Freeman \& Thacker (2011) demonstrated that 3 HMA species each had a unique

31 interaction with their respective symbiont community and this was ultimately ascribed to the

32 presence or absence of productive photosymbiont taxa across different sponge species (Freeman

33 et al., 2013). In addition, with increasing evidence supporting the assimilation of dissolved

34 organic matter (DOM) (Maldonado, Ribes \& van Duyl, 2012; de Goeij et al., 2013), it is apparent

35 that there is substantial metabolic diversity across sympatric sponge species. 
This diversity may allow for the expansion of sponge species across available niche space

37 within crowded tropical reef environments, potentially relaxing competition and contributing to

38 the diversification of these communities (Knowlton \& Jackson, 1994; Beinart et al., 2012; Joy,

39 2013). Unfortunately, our understanding of the relative positions of diverse sponge species within

40 the available niche space of a reef remains limited. The relative placement of an organism within

41 a food web has long been assessed using the stable isotopes of $\mathrm{C}$ and $\mathrm{N}\left(\delta^{13} \mathrm{C}\right.$ and $\left.\delta^{15} \mathrm{~N}\right)($ Fry,

42 2006). Because an organism's position in bivariate $\left(\delta^{13} \mathrm{C}\right.$ and $\left.\delta^{15} \mathrm{~N}\right)$ "isotopic space" is directly

43 related to the sources of $\mathrm{C}$ and $\mathrm{N}$ assimilated, biochemical processing of these sources, and the

44 habitat where an organism is found, the relative placement of a consumer in this space has been

45 equated with the "niche" space it fills within a system (Layman et al., 2007a; Newsome et al.,

46 2007; Layman et al., 2012). Qualitative assessments of an organism's niche are possible with $\delta^{13} \mathrm{C}$

47 and $\delta^{15} \mathrm{~N}$ biplots, and these analyses have been widely used to investigate sponge metabolism

48 (Weisz, 2006; Thurber, 2007; Weisz et al., 2007; Mohamed et al., 2008; Freeman \& Thacker,

49 2011; van Duyl et al., 2011; Fiore, Baker \& Lesser, 2013). Quantitative assessments of niche

50 space have recently been described and used to study trophic diversity and investigate changes in

51 the size and structure of a community or population (Layman et al., 2007a; 2007b; Layman et al.,

52 2012). Recent analytical methods also provide a means to evaluate the relative placement of a

53 consumer or guild within isotopic space (Turner, Collyer \& Krabbenhoft, 2010).

54 We adapted these methods to calculate the niche size and relative placement of HMA and

55 LMA groups and individual sponge species within isotopic niche space (Turner, Collyer \&

56 Krabbenhoft, 2010; Jackson et al., 2011). Sponges for this study were collected from 14 sites

57 within the Miskito Cays of Honduras during a May 2013 expedition in this archipelago (Chollett,

58 Stoyle \& Box, 2014). As part of this expedition, sponge communities were surveyed and sampled

59 to gain an understanding of the diversity of conspicuous, common sponge species and to assess 
60 the status of sponge-microbe symbioses on these largely undescribed and isolated Caribbean

61 reefs. These reefs are distant from chronic anthropogenic stressors (Hay, 1984; Chollett, Stoyle \&

62 Box, 2014) and thus may provide a baseline understanding of how diverse sponges fill isotopic

63 niche space in oligotrophic systems that can be compared to more eutrophic systems throughout

64 the greater Caribbean. We test the following null hypotheses: 1) niche size is similar between

65 HMA and LMA groups and across individual sponge species, and 2) HMA and LMA groups and

66 individual sponge species occupy similar niche space within a reef system.

\section{Materials \& Methods}

68 Study Site and Collection

69 The Miskito Cays are an archipelago of 49 small (average 0.59 hectares) islands

70 representing about $750 \mathrm{~km}^{2}$ of benthic habitat located approximately $300 \mathrm{~km}$ east of the Bay

71 Islands and $70 \mathrm{~km}$ off the northeast coast of Honduras (Chollett, Stoyle \& Box, 2014). Sponge

72 diversity was assessed qualitatively at 14 sites within this region (Table 1; see map in Chollett,

73 Stoyle \& Box, 2014) by recording the presence or absence of apparent, non-cryptic sponge

74 species. When possible, at least three replicate samples of each common species were collected at

75 a site for $\delta^{13} \mathrm{C}$ and $\delta^{15} \mathrm{~N}$ values and chlorophyll $a(\operatorname{chl} a)$ analyses, along with a carboy of water

76 collected at depth for the measurement of $\delta^{13} \mathrm{C}$ and $\delta^{15} \mathrm{~N}$ values of particulate organic matter

77 (POM), a potential source of $\mathrm{C}$ and $\mathrm{N}$ for sponges feeding heterotrophically (Freeman \& Thacker,

78 2011). Because filtration of water for POM was restricted to the use of a hand pump, collections

79 for POM were limited to a single carboy at each site.

80 After each dive, sponge samples were catalogued and, because sponges could not be

81 frozen for the duration of the expedition, samples were dried for $36 \mathrm{~h}$ at $60^{\circ} \mathrm{C}$ using the Nesco

82 FD-75A $700 \mathrm{~W}$ food dehydrator. Water samples were filtered through a $0.70 \mu \mathrm{m}$ GF filter under

83 low pressure generated via a hand pump to obtain POM as in Freeman \& Thacker (2011); filters 
84 were wrapped in aluminum foil and dried for $24 \mathrm{~h}$ in the dehydrator as above. These collections

85 were organized and authorized through an agreement between the Centre for Marine Studies, a

86 Honduran non-governmental organization, and the national government; the Smithsonian

87 Institution provided technical support. These sponge species are not listed within the CITES

88 appendices and are not protected within Honduras.

$89 \delta^{13} C$ and $\delta^{15} N$ and Chlorophyll a Analyses

90 At the Smithsonian Marine Station in Fort Pierce, Florida, USA, sponge samples were

91 placed in a $60^{\circ} \mathrm{C}$ oven to remove any residual moisture and ground to a fine powder using a

92 mortar and pestle. Homogenized sponge tissue was acidified to remove carbonate and weighed

93 into tared silver capsules for $\delta^{13} \mathrm{C}$ and $\delta^{15} \mathrm{~N}$ as in Freeman \& Thacker (2011). Sponge and POM

94 samples were analyzed in the Stable Isotope Ratio Mass Spectrometry laboratory (SIRMS) at the

95 University of Hong Kong via combustion in a Eurovector EA3028 coupled to a Perspective

96 IRMS (Nu Instruments). Analytical precision was determined by repeated analysis of an internal

97 acetanilide standard ('acet 6’; 70\% C). Mean ( \pm SE) precision during analysis was $0.2 \pm 0.04$ and

$980.1 \pm 0.01$ for $\delta^{15} \mathrm{~N}$ and $\delta^{13} \mathrm{C}$, respectively. To assess photosymbiont abundance (chl $a$ ), analyses

99 were carried out on dried tissue as in Freeman \& Thacker (2011) and Freeman et al. (2013).

100 Data Analysis

101 Isotopic niche area of LMA and HMA groups and individual sponge species was

102 estimated by calculation of the standard ellipse area $\left(\mathrm{SEA}_{c}\right)$ using a Bayesian approach based on

103 multivariate ellipse-based metrics (SIBER [Stable Isotope Bayesian Ellipses in R]; Jackson et al.,

104 2011). The $\mathrm{SEA}_{\mathrm{c}}$ contains approximately $40 \%$ of the data within a set of bivariate data and thus

105 represents the core niche area for a population or community (Jackson et al., 2011; Layman et al.,

106 2012). Unlike previous estimates of niche width (by measuring the area of a convex hull

107 enclosing all data points [Total Area TA; Layman et al., 2007a]), SEA calculations are less 
108 susceptible to outlying data points. In addition, estimation of these ellipses by Bayesian inference

109 allows for robust comparison across sets of data with different sample sizes. We adapted these

110 methods to first investigate differences in the size and overlap of the SEA $A_{c}$ of LMA and HMA

111 sponges at sites within the Miskito Cays. Because our goals using SEA $A_{c}$ were to 1) visualize the

112 variation within each of these well-established guilds of sponges and 2) quantify and compare the

113 core niche areas for each of these groups, $\mathrm{SEA}_{\mathrm{c}}$ was calculated for each group from $\delta^{13} \mathrm{C}$ and $\delta^{15} \mathrm{~N}$

114 values of individual sponge samples (Turner \& Edwards, 2012). Likewise, to compare the niche

115 area of individual species, the $\mathrm{SEA}_{\mathrm{c}}$ of each species was calculated by the dispersion of $\delta^{13} \mathrm{C}$ and

$116 \delta^{15} \mathrm{~N}$ values of each species within isotopic space (Jackson et al., 2011). For all analyses, residuals

117 from General Linear Models were tested for normality and equal variance using Kolmogorov-

118 Smirnov and Levene's tests, respectively.

119 In addition to the calculation of $\mathrm{SEA}_{\mathfrak{c}}$, we compared the placement of HMA and LMA

120 groups and individual species in isotopic niche space using methods outlined by Turner, Collyer

$121 \&$ Krabbenhoft (2010). These methods calculate the Euclidean distance between the centroids

122 (bivariate mean) of guilds or individual species within isotopic space and use a residual

123 permutation procedure (RPP) and Hotelling $\mathrm{T}^{2}$ test to evaluate whether this distance is significant

124 (different from zero), thus placing these groups or individual species in unique isotopic space

125 (Turner, Collyer \& Krabbenhoft, 2010). Finally, to quantify the relative effects of microbial

126 abundance, chlorophyll $a$ concentration, and host species identity on the placement of samples

127 with the isotopic space of the Miskito Cays, we calculated isotopic dissimilarity among samples.

128 This was accomplished by creating a distance matrix from our $\delta^{13} \mathrm{C}$ and $\delta^{15} \mathrm{~N}$ data and analyzing

129 sample distances using the R function adonis in the package vegan (Oksanen et al., 2014).

\section{Results}


131 Sponges were sampled at 14 sites spanning over $100 \mathrm{~km}$ of the Miskito Cays (Table 1;

132 Chollett, Stoyle \& Box 2014). We catalogued 25 species of sponges, with substantial variation in

133 species diversity (Table 2) across sites. Because collections were limited to single dives at each

134 site and not all species were abundant at each site, replicate individuals of a species observed

135 were not always collected. For instance, although site ML4 was extremely diverse, we were only

136 able to collect replicate individuals of five species from this site. Collections at two of the most

137 diverse sites, Media Luna \#s 2 and 3 (ML2 and ML3), were the most complete (Table 2), so

138 within site comparisons are focused on these sites. Particulate organic matter (POM) from 6 sites

139 within Miskito Cays had a mean ( $\pm \mathrm{SE}$ ) value of $3.7 \% \pm 0.6$ and $-22.7 \% \pm 0.5$ for $\delta^{15} \mathrm{~N}$ and

$140 \delta^{13} \mathrm{C}$, respectively, with a range in $\delta^{15} \mathrm{~N}$ values of $0.9 \%$ (Site ML4) to $5.5 \%$ (Vivorillos Site 1 )

141 and $\delta^{13} \mathrm{C}$ values of $-24.1 \%$ (Site ML2) to $-21.2 \%$ (Site ML4). We were unable to obtain

142 accurate $\mathrm{C}$ and $\mathrm{N}$ values of $\mathrm{POM}$ at some sites due to low signal strength resulting from low

143 organic biomass on filters.

144 Photosymbiont abundance (as measured by chlorophyll $a[\mathrm{chl} a]$ ) was highly variable

145 across the 19 most common sponge species collected within this region. Of these species, 10 have

146 been previously categorized as HMA and 8 as LMA (Weisz, 2006; Weisz et al., 2007; Thacker \&

147 Freeman, 2012; Maldonado, Ribes \& van Duyl, 2012; Gloeckner et al., 2014). Although

148 Desmapsamma anchorata has yet to be placed within one of these groups, because this species is

149 characterized by low chl $a$ concentration and lacks defined symbionts (Figure 1; Erwin \&

150 Thacker, 2007), it has been included within the LMA group. Six of the 19 species (all of which

151 are HMA species) are considered to have high $\operatorname{chl} a$ concentrations (chl $a>125 \mu \mathrm{g}$ of chl a; as in

152 Erwin \& Thacker, 2007), while all of the LMA species were well below this cutoff. Four of the

15310 HMA species had low concentrations of chl $a$ (Figure 1; Gloeckner et al., 2014). 
Although SIBER analyses showed a $31 \%$ overlap of HMA and LMA species within the

155 isotopic niche space of the Miskito Cays, HMA sponges displayed a broader niche width (greater

$156 \mathrm{SEA}_{c}$ ) than LMA sponges $(\mathrm{P}<0.0001)$ (Figure 2a). We have included the TA metric (Total Area of

157 convex hulls) in figures as a reference, but the remaining results and discussion will focus solely

158 on $\mathrm{SEA}_{\mathrm{c}}$ as a measure of niche area, which is less sensitive to variation in sample size than TA

159 based on convex hulls (Figure 2a; Layman et al., 2007a; Jackson et al., 2011). Each of these two

160 groups fills unique isotopic niche space within the Miskito Cays (distance between

161 centroids $=1.45$; Hotelling's $\mathrm{T}$ test: $\mathrm{T}^{2}=119.21, \mathrm{~F}=58.85, \mathrm{P}<0.0001$ ) (Figure 2a). When HMA

162 sponges are further delineated into species with high (HMA-H) and low (HMA-L) chl $a$ values,

163 the SEA ${ }_{c}$ of HMA-H species is significantly larger than that of both HMA-L and LMA groups

$164(\mathrm{P}<0.01)$ (Figure 2b). In addition, HMA-H sponges occupied a unique location in isotopic niche

165 space compared to both HMA-L (57 \% SEA $\mathrm{s}_{c}$ overlap; distance between centroids $=1.50$;

166 Hotelling's $\mathrm{T}$ test: $\left.\mathrm{T}^{2}=43.68, \mathrm{~F}=21.28, \mathrm{P}<0.001\right)$ and LMA sponges $\left(<0.1 \% \mathrm{SEA}_{\mathrm{c}}\right.$ overlap;

167 distance between centroids=1.71; Hotelling's $T$ test: $T^{2}=177.21, \mathrm{~F}=87.38, \mathrm{P}<0.001$ ). Although the

$168 \mathrm{SEA}_{\mathrm{c}}$ of the HMA-L species was significantly larger than that of the LMA group $(\mathrm{P}=0.029)$,

169 LMA and HMA-L species occupied similar isotopic niche space (66.7\% SEA $\mathrm{A}_{c}$ overlap; distance

170 between centroids $=0.25$; Hotelling's $\mathrm{T}$ test: $\mathrm{T}^{2}=1.44, \mathrm{~F}=0.70, \mathrm{P}=0.492$ ) (Figure 2b). The

171 placement of individual samples within the isotopic space of the Miskito Cays was significantly

172 impacted by microbial abundance (adonis effect of HMA/LMA: $\mathrm{df}=1, \mathrm{~F}=62.12, \mathrm{R}^{2}=0.21$,

$173 \mathrm{P}<0.01$ ), but was better explained by modified microbial abundance (adonis effect of HMA-H,

174 HMA-L, and LMA: $\mathrm{df}=2, \mathrm{~F}=44.59, \mathrm{R}^{2}=0.27, \mathrm{P}<0.01$ ). An equal amount of variance in sample

175 placement within isotopic space was explained by chlorophyll $a$ concentration alone (adonis

176 effect of chl $a$ concentration (high or low): $\mathrm{df}=1, \mathrm{~F}=88.57, \mathrm{R}^{2}=0.27, \mathrm{P}<0.01$ ). In addition, when

177 chlorophyll $a$ concentration and modified microbial abundance were tested together in the same

178 equation using adonis, it was apparent that these factors explained the same portion of the 
179 variance, implying that chlorophyll $a$ concentration was the main explanatory factor for

180 determining sponge placement within isotopic space.

181 At ML2, the SEA $A_{c}$ of HMA species was also significantly larger than that of LMA species

$182(\mathrm{P}<0.01)$, there was no overlap in the $\mathrm{SEA}_{\mathrm{c}}$ of these two groups, and each of these groups

183 occupied unique niche space (distance between centroids=1.84; Hotelling's $\mathrm{T}$ test: $\mathrm{T}^{2}=85.95$,

$184 \mathrm{~F}=40.50, \mathrm{P}<0.0001$ ) (Figure 3a). Likewise, at site ML3, the $\mathrm{SEA}_{\mathrm{c}}$ of HMA species was

185 significantly larger than that of LMA species $(0 \%$ of the simulated LMA SEA were greater than

186 those of HMA holobionts) (Figure 3b) and each of these two groups occupied unique isotopic

187 niche space (distance between centroids=1.39; Hotelling's $\mathrm{T}$ test: $\mathrm{T}^{2}=24.68, \mathrm{~F}=11.55, \mathrm{P}<0.0001$ ).

188 At site ML3, there was substantial (31.7\%) overlap in the SEA ${ }_{c}$ generated by LMA and HMA

189 holobionts. Because collections at ML3 included members of both HMA-H and HMA-L species,

190 we repeated this analysis with the three groups (HMA-L, HMA-H, and LMA). Although the

191 SEA $\mathrm{A}_{\mathrm{c}}$ of HMA-H and HMA-L groups were similar in size $(\mathrm{P}=0.671)$, the $\mathrm{SEA}_{c}$ of both HMA

192 groups were greater than that of LMA sponges $(\mathrm{P}<0.007)$. While there was no overlap between

193 HMA-H and either HMA-L or LMA sponges, these latter two groups overlapped by almost $40 \%$

194 (Figure 3c). Each of these 3 groups occupied unique isotopic niche space within ML3 (HMA-H

195 and HMA-L: distance between centroids $=1.89$; Hotelling's $\mathrm{T}$ test: $\mathrm{T}^{2}=23.85, \mathrm{~F}=9.69, \mathrm{P}=0.001$;

196 HMA-H and LMA: distance between centroids $=2.55$; Hotelling's $\mathrm{T}$ test: $\mathrm{T}^{2}=58.08, \mathrm{~F}=25.81$,

$197 \mathrm{P}<0.0001$; HMA-L and LMA: distance between centroids $=0.71$; Hotelling's $\mathrm{T}$ test: $\mathrm{T}^{2}=7.19$,

$198 \mathrm{~F}=3.15, \mathrm{P}=0.046)$.

199 Separate SIBER analysis on each of the 19 sponge species from across all sites within the

200 Miskito Cays increased our resolution of the dispersion of different holobionts within isotopic

201 space (Figure 4). Although pairwise differences in the size of SEA $A_{c}$ were widespread, we limit

202 our discussion of these data as some, but not all species were collected from disparate sites.

203 Within the isotopic niche space of the Miskito Cays, 4 of the 6 HMA-H species (Aplysina spp., I. 
204 campana, and C. caribensis) were isolated from LMA sponges, while the other 2 HMA-H species

205 (N. rosariensis and V.rigida) overlapped with one or more LMA species. Likewise, the HMA-L

206 Agelas spp. overlapped with at least one LMA sponge, while the HMA-L species E. ferox

207 overlapped with A. cauliformis and was distant in space from LMA species. The ellipses

208 representing the LMA species were concentrated in one region of isotopic niche space, with

209 substantial overlap, whereas the SEA of HMA species were more widespread (Figure 4). Host

210 species identity accounted for nearly $75 \%$ of the variation in isotope values across all individuals

211 (adonis effect of species: $\mathrm{df}=18, \mathrm{~F}=34.38, \mathrm{R}^{2}=0.74, \mathrm{P}<0.01$ ).

212 Although there was no significant difference in the size of the $\mathrm{SEA}_{\mathrm{c}}$ across species within

213 sites ML2 and ML3 due to limited statistical power in SIBER as a result of low sample size, there

214 was substantial variation in the placement of each species within isotopic niche space within

215 these sites (Figures 5a and 5b). Within ML2, some species were present in unique niche space ( $I$.

216 campana, C. caribensis, C. fallax, and A. compressa), while other species shared niche space

217 with at least one other species (the HMA Aplysina spp; the HMA species V. rigida and the LMA

218 species M. arbuscula and N. erecta; and the LMA species C. vaginalis and I. birotulata and $M$.

219 laevis; Figure 5a). Similar results were observed in the 11 species collected from ML3 (Figure

220 5b), where the HMA species A. cauliformis, E. ferox and I. campana each occupied a unique

221 location within isotopic space at this site, while other species shared niche space with at least one

222 other species.

\section{Discussion}

224 This study supports the contention that biogeochemical cycling of $\mathrm{C}$ and $\mathrm{N}$ is highly

225 variable across sponge species and provides initial evidence that this variation is driven more by

226 host species identity than by overall symbiont abundance. These reefs within the Miskito Cays of

227 Honduras support diverse sponge communities that are taxonomically similar to those of other

228 Caribbean reefs (Díaz, 2005; Erwin \& Thacker, 2007; Chollett, Stoyle \& Box, 2014) and include 
229 species hosting both abundant and sparse microbial taxa (HMA and LMA, respectively; Thacker

$230 \&$ Freeman, 2012). In addition, species from this region spanned a striking gradient of

231 photosymbiont abundance (Erwin \& Thacker, 2007) with some, but not all HMA sponges

232 supporting abundant photosymbiont communities.

233 Symbionts within HMA species appear to increase holobiont metabolic diversity, leading

234 to broader niche area $\left(\mathrm{SEA}_{\mathrm{c}}\right)$ than that observed in LMA species (Boucher, James \& Keeler,

235 1982; Vrijenhoek, 2010). In addition, the separation of HMA and LMA groups suggests that

236 biogeochemical cycling of $\mathrm{C}$ and $\mathrm{N}$ is distinct between HMA and LMA species and that, by

237 hosting abundant symbiont communities, HMA species expand into novel isotopic niche space

238 (Weisz et al., 2007). Although microbial abundance accounted for a significant portion of the

239 variance in isotopic values across the Miskito Cays, this variance was better explained by

240 chlorophyll $a$ concentrations, implying that photosymbiont metabolism is an important predictor

241 in the placement of species in isotopic space (Wilkinson, 1983; Stanley, 2006; Venn, Loram \&

242 Douglas, 2008). While species lacking photosymbionts may be largely restricted to heterotrophic

243 feeding to meet their energy demands, abundant microbial communities within HMA-L sponges

244 may assimilate diverse sources of DOM (Maldonado, Ribes \& van Duyl, 2012) or may utilize

245 chemoautotrophic pathways to fix nutrients (Taylor et al., 2007). With increasing evidence that

246 sponge cells can directly assimilate DOM and that many LMA species have moderate OTU

247 richness, supplemental nutrition via DOM may also occur in some LMA species (de Goeij et al.,

248 2013; Easson \& Thacker, 2014).

249 Species accounts for a significant ( $74 \%)$ portion of the variance in isotope values within

250 the Miskito Cays, suggesting that biogeochemical C and N cycling is highly variable across host

251 species. Indeed, the unique placement of individual species within isotopic niche space may

252 reflect the assimilation of unique sources of $\mathrm{C}$ and $\mathrm{N}$ or species-specific biological and chemical

253 processes occurring during the transformation and cycling of these nutrients within the holobiont 
254 (Weisz, 2006; Newsome et al., 2007; Taylor et al., 2007; Southwell, Popp \& Martens, 2008; Fiore

255 et al., 2010; Layman et al., 2012; Fiore, Baker \& Lesser, 2013). For instance, some holobionts

256 may fix and further transform inorganic sources of $\mathrm{C}$ and $\mathrm{N}$ (Mohammed et al., 2008;

257 Maldonado, Ribes \& van Duyl, 2012; Freeman et al., 2013), while other holobionts could be

258 utilizing a combination of inorganic and organic sources or relying solely on local sources of

259 dissolved or particulate organic matter (van Duyl et al., 2011; Maldonado, Ribes \& van Duyl,

260 2012; Thacker \& Freeman, 2012). In addition, disparity in the placement of species could be

261 reflective of specialization on particular size fractions of the pelagic microbial loop (Thurber,

262 2007) or variation in the proportional use of diverse DOM sources (coral mucus, phytoplankton,

263 and benthic algae [including crustose coralline algae-CCAs] (van Duyl et al., 2011). Coupling

264 these analyses with comprehensive sampling of potential sources of nutrients, feeding

265 experiments with labeled organic and inorganic sources of $\mathrm{C}$ and $\mathrm{N}$, and fatty acid analysis may

266 help to better elucidate resource use by diverse holobionts in reef systems (Thurber, 2007; van

267 Duyl et al., 2011; Maldonado, Ribes \& van Duyl, 2012).

268 The strong effect of host species identity on the placement of individuals within isotopic

269 space may be driven by a high degree of host-specificity in these interactions. For instance, a

270 recent study by Easson \& Thacker (2014) showed that microbial community diversity within 20

271 HMA and LMA species (including 9 species from the current study) was strongly influenced by

272 host phylogeny. Importantly, even closely related host species had strikingly different microbial

273 communities, implying strong selection for divergent microbial communities across sympatric

274 sponge species and suggesting a potential role of microbial symbionts in niche differentiation

275 (Easson \& Thacker, 2014). Although we did not evaluate the microbial community composition

276 in sponges from the Miskito Cays, additional work directly investigating how microbial

277 community composition (Webster et al., 2010; Webster \& Taylor, 2012; Schmitt et al., 2012) and 
278 function (Stat, Morris \& Gates, 2008; Thomas et al., 2010; Radax et al., 2012) impact the

279 placement of sponges in isotopic niche space is certainly warranted.

280 Coral reefs contain a staggering diversity of potential sources of $\mathrm{C}$ and $\mathrm{N}$ that are

281 available to sponges, and our understanding of these sources, how they change across sites, and

282 their respective isotope values is still being expanded (Freeman \& Thacker, 2011; Maldonado,

283 Ribes \& van Duyl, 2012; deGoeij et al., 2013). With so many sources, some of which may have

284 overlapping isotope values, it is difficult to construct effective and accurate mixing models,

285 especially with only two isotopes (Layman et al., 2012). Thus, instead of estimating the relative

286 contribution of nutrient sources to each holobiont, we used standardized methods to visualize the

287 relative position of diverse holobionts within the isotopic niche space of oligotrophic reefs,

288 providing an important baseline to which future research can be compared. For instance, across

289 gradients from pristine to impacted or tropical to temperate reefs, we might hypothesize that the

290 abundance and diversity of potential nutrient sources would increase, potentially relaxing

291 holobiont dependence on symbiont metabolism and resulting in increased overlap in the SEA $\mathrm{c}_{\mathrm{c}}$ of

292 HMA and LMA groups, as well as of individual species in isotopic niche space (Turner, Collyer

293 \& Krabbenhoft, 2010; Layman et al., 2012). Research using these methods to understand how

294 sponge communities and individual species respond to environmental gradients is ongoing as part

295 of the Smithsonian Institution's Marine Global Earth Observatories (MarineGEO) initiative.

296 Conducting similar studies in unison with community-based metrics outlined by Layman et al.

297 (2007a) may also help us understand how dominant functional groups partition available

298 resources within reef systems and the community-wide response to environmental change

299 (Layman et al., 2007b).

300 In conclusion, we show that diverse sponge species fill available isotopic niche space

301 within oligotrophic reefs and that, by hosting abundant symbiont communities, sponges are able

302 to expand beyond the isotopic space occupied by LMA species. The placement of individual 
303 sponges within this isotopic space, however, may be driven more by the presence or absence of

304 particular microbial taxa than by overall symbiont or photosymbiont abundance (Thacker \&

305 Freeman, 2012). We posit that, as these interactions have evolved, the acquisition and

306 establishment of physiologically unique symbionts may have enabled some host species to

307 expand into novel physiochemical niches (Moran, 2007; Taylor et al., 2007; Thacker \& Freeman,

308 2012). Such expansion may support the coexistence of diverse sponge taxa within crowded reef

309 systems.

310 Acknowledgements

311 We thank the staff of the Smithsonian Marine Station for their logistical support. In particular, we

312 thank S. Reed and M. Teplitski for their assistance in the field and S. Box for technical support.

313 We also thank V. Paul and two reviewers for their helpful comments. M. Zhu and H. Wong

314 assisted with isotope analyses. This is contribution number 971 from the Smithsonian Marine

315 Station at Fort Pierce.

\section{References}

317 Baker DM, Andras JP, Jordán-Garza A, Fogel ML. 2013. Nitrate competition in $318 \quad a$ coral symbiosis varies with temperature among Symbiodinium clades.

$320 \quad$ The ISME Journal 7:1248-1251.

321 Beinart RA, Sanders JG, Faure B, Sylva SP, Lee RW, Becker EL, Gartman A, Luther GW, 322 Seewald JS, Fisher CR, Girguis PR. 2012. Evidence for the role of endosymbionts in 323 regional-scale habitat partitioning by hydrothermal vent symbioses. Proceedings of 324 the National Academy of Sciences, USA 109:3241-3250. 
325 Boucher DH, James S, Keeler KH. 1982. The ecology of mutualism. Annual

326 Review of Ecology, Evolution, and Systematics 13:315-347.

327 Chollett I, Stoyle G, Box S. 2014. Honduran Miskito Cays: among the last

328 unexplored reef systems in the Caribbean. Coral Reefs 33:155.

329 de Goeij JM, van Oevelen D, Vermeij MJA, Osinga R, Middelburg JJ, de Goeij

330 AFPM, Admiraal W. 2013. Surviving in a marine desert: The sponge loop

331 retains resources within coral reefs. Science 342:108-110.

332 Díaz MC. 2005. Common sponges from shallow marine habitats from Bocas

333 del Toro region, Panama. Caribbean Journal of Science 41:465-475.

334 Easson CG, Thacker RW. 2014. Phylogenetic signal in the community

335 structure of host-specific microbiomes of tropical marine sponges.

336 Frontiers in Microbiology 5:1-11.

337 Erwin PM, Thacker RW. 2007. Incidence and identity of photosynthetic

338 symbionts in Caribbean coral reef sponge assemblages. Journal of the

339 Marine Biological Association of the United Kingdom 87:1683-1692.

340 Fiore CL, Jarett JK, Olson ND, Lesser MP. 2010. Nitrogen fixation and nitrogen

341 transformations in marine symbioses. Trends in Microbiology 18:455-

342463.

343 Fiore CL, Baker DM, Lesser MP. 2013. Nitrogen biogeochemistry in the

344 Caribbean sponge, Xestospongia muta: A source or sink of dissolved

345 inorganic nitrogen? PLOS ONE 8:e72961.

346 doi:10.1371/journal.pone.0072961. 
347 Freeman CJ, Thacker RW. 2011. Complex interactions between marine

348 sponges and their symbiotic microbial communities. Limnology and

$349 \quad$ Oceanography 56:1577-1586.

350 Freeman CJ, Thacker RW, Baker DM, Fogel M. 2013. Quality or quantity: is

351 nutrient transfer driven more by symbiont identity and productivity than

352 by symbiont abundance? The ISME Journal 7:1116-1125.

353 Fry B. 2006. Stable Isotope Ecology. New York: Springer.

354 Gloeckner V, Wehrl M, Moitinho-Silva L, Gernert C, Schupp P, Pawlik JR,

355 Lindquist NL, Erpenbeck D, Wörheide G, Hentschel U. 2014. The HMA-

356 LMA dichotomy revisited: an electron microscopical survey of 56 sponge

357 species. Biological Bulletin 227:78-88.

358 Hay ME. 1984. Patterns of fish and urchin grazing on Caribbean coral reefs:

$359 \quad$ Are previous results typical? Ecology 65:446-454.

360 Jackson AL, Inger R, Parnell A, Bearhop S. 2011. Comparing isotopic niche

361 widths among and within communities: SIBER-Stable Isotope Bayesian

362 Ellipses in R. Journal of Animal Ecology 80:595-602.

363 Joy JB. 2013. Symbiosis catalyses niche expansion and diversification. Proceedings of the Royal

$364 \quad$ Society B 280:1-7.

365 Knowlton N, Jackson JBC. 1994. New taxonomy and niche partitioning on

366 coral reefs: jack of all trades or master of some? Trends in Ecology \&

367 Evolution 9:7-9.

368 Layman CA, Arrington DA, Montaña CG, Post DM. 2007a. Can stable isotope

369 ratios provide quantitative measures of trophic diversity within food

370 webs? Ecology 88:42-48. 
371 Layman CA, Quattrochi JP, Peyer CM, Allgeier JE. 2007b. Niche width collapse

372 in a resilient top predator following ecosystem fragmentation. Ecology

373 Letters 10:937-944.

374 Layman CA, Araujo MS, Boucek R, Harrison E, Jud ZR, Matich P,

375 Hammerschlag-Peyer CM, Rosenblatt AE, Vaudo JJ, Yeager LA, Post D,

376 Bearhop S. 2012. Applying Stable Isotopes to Examine Food Web

377 Structure: An Overview of Analytical Tools. Biological Reviews 87:542-

378562.

379 Maldonado M, Ribes M, van Duyl FC. 2012. Nutrient fluxes through sponges:

380 biology, budgets, and ecological implications. Advances in Marine

381 Biology 62:113-182.

382 Mohamed NM, Colman AS, Tal Y, Hill RT. 2008. Diversity and expression of

383 nitrogen fixation genes in bacterial symbionts of marine sponges.

384 Environmental Microbiology 10:2910-2921.

385 Moran NA. 2007. Symbiosis as an adaptive process and source of phenotypic 386 complexity. Proceedings of the National Academy of Sciences, USA $387 \quad 104: 8627-8633$.

388 Moya A, Peretó J, Gil R, Latorre A. 2008. Learning how to live together:

389 genomic insights into prokaryote-animal symbioses. Nature Review $390 \quad$ Genetics 9:218-229.

391 Muscatine L, Cernichiari E. 1969. Assimilation of photosynthetic products of 392 zooxanthellae by a reef coral. Biological Bulletin 137:506-523. 
393 Muscatine L, Porter JW, Kaplan IR. 1989. Resource partitioning by reef corals 394 as determined from stable isotope composition $\mathrm{I} . \delta^{13} \mathrm{C}$ of zooxanthellae 395 and animal tissue vs depth. Marine Biology 100:185-193.

396 Newsome SD, Del Rio CM, Bearhop S, Phillips DL. 2007. A niche for isotopic 397 ecology. Frontiers in Ecology and the Environment 5:429-436.

398 Oksanen J, Blanchet FG, Kindt R, Legendre P, Minchin PR, O'Hara RB,

399 Simpson GL, Solymos P, Stevens MHH, Wagner H. 2014. Vegan:

400 Community Ecology Package. Available online at: http://cran.r$401 \quad$ project.org/web/packages/vegan.

402 Radax R, Rattei T, Lanzen A, Bayer C, Rapp HT, Urich T, Schleper C. 2012.

403 Metatranscriptomics of the marine sponge Geodia barretti: tackling 404 phylogeny and function of its microbial community. Environmental $405 \quad$ Microbiology 14:1308-1324.

406 Rosenberg E, Koren O, Reshef L, Efrony R, Zilber-Rosenberg I. 2007. The role 407 of microorganisms in coral health, disease and evolution. Nature $408 \quad$ Reviews Microbiology 5:355-362.

409 Schmitt S, Tsai P, Bell J, Fromont J, Ilan M, Lindquist N, Perez T, Rodrigo A, 410 Schupp PJ, Vacelet J, Webster N, Hentschel U, Taylor MW. 2012.

411 Assessing the complex sponge microbiota: Core, variable, and species412 specific bacterial communities in marine sponges. The ISME Journal $413 \quad 6: 564-576$.

414 Southwell MW, Popp BN, Martens CS. 2008. Nitrification controls on fluxes 415 and isotopic composition of nitrate from Florida Keys sponges. Marine $416 \quad$ Chemistry 108:96-108. 
417 Stanley GD. 2006. Photosymbiosis and the evolution of modern coral reefs.

$418 \quad$ Science 312:857-858.

419 Stat M, Morris E, Gates RD. 2008. Functional diversity in coral-dinoflagellate

420 symbiosis. Proceedings of the National Academy of Sciences, USA

$421 \quad 105: 9256-9261$.

422 Taylor MW, Radax R, Steger D, Wagner M. 2007. Sponge-associated

423 microorganisms: evolution, ecology, and biotechnological potential.

424 Microbiology and Molecular Biology Reviews 71:295-347.

425 Thacker RW, Freeman CJ. 2012. Sponge-microbe symbioses: Recent

426 advances and new directions. Advances in Marine Biology 62:57-111.

427 Thomas T, Rusch D, DeMaere MZ, Yung PY, Lewis M, Halpern A, Heidelberg

428 KB, Egan S, Steinberg PD, Kjelleberg S. 2010. Functional genomic

429 signatures of sponge bacteria reveal unique and shared features of

$430 \quad$ symbiosis. The ISME Journal 4:1557-1567.

431 Thurber AR. 2007. Diets of Antarctic sponges: links between the pelagic

432 microbial loop and benthic metazoan food web. Marine Ecology Progress

$433 \quad$ Series 351:77-89.

434 Turner TF, Collyer ML Krabbenhoft TJ. 2010. A general hypothesis-testing

435 framework for stable isotope ratios in ecological studies. Ecology

$43691: 2227-2233$.

437 Turner TF, Edwards MS. 2012. Aquatic foodweb structure of the Rio Grande 438 assessed with stable isotopes. Freshwater Science 31:825-834.

439 van Duyl FC, Moodley L, Nieuwland G, van Ijzerloo L, van Soest RWM, $440 \quad$ Houtekamer M, Meesters EH, Middelburg JJ. 2011. Coral cavity sponges 
441 depend on reef-derived food resources: Stable isotope and fatty acid 442 constraints. Marine Biology 158:1653-1666.

443 Venn AA, Loram JE, Douglas AE. 2008. Photosynthetic symbioses in animals. $444 \quad J o u r n a l$ of Experimental Botany 59:1069-1080.

445 Vrijenhoek RC. 2010. Genetics and evolution of deep-sea chemosynthetic 446 bacteria and their invertebrate hosts. In: Kiel S, ed. The vent and seep 447 biota, Topics in Geobiology 33. Berlin: Springer, 15-50.

448 Webster NS, Taylor MW, Behnam F, Lücker S, Rattei T, Whalan S, Horn M, 449 Wagner M. 2010. Deep sequencing reveals exceptional diversity and 450 modes of transmission for bacterial sponge symbionts. Environmental $451 \quad$ Microbiology 12:2070-2082.

452 Webster NS, Taylor MW. 2012. Marine sponges and their microbial symbionts: 453 love and other relationships. Environmental Microbiology 14:335-346.

454 Weisz JB. 2006. Measuring impacts of associated microbial communities on 455 Caribbean reef sponges: searching for symbiosis. D. Phil. Thesis, $456 \quad$ University of North Carolina at Chapel Hill.

457 Weisz JB, Hentschel U, Lindquist N, Martens CS. 2007. Linking abundance 458 and diversity of sponge-associated microbial communities to metabolic 459 differences in host sponges. Marine Biology 152:475-483.

460 Wilkinson CR. 1983. Net primary productivity in coral reef sponges. Science $461 \quad 219: 410-412$.

462 Zilber-Rosenberg I, Rosenberg E. 2008. Role of microorganisms in the 463 evolution of animals and plants: the hologenome theory of evolution. 464 FEMS Microbiology Reviews 32:723-735. 
465 Figure 1: Mean Chlorophyll $a(\mathrm{Chl} a)$ concentration ( $\pm \mathrm{SE})$ of 19 common sponge species 466 collected within the Miskito Cays of Honduras. Sponges are categorized based on their overall 467 microbial abundance into High Microbial Abundance (HMA) and Low Microbial Abundance 468 (LMA) groups (Weisz, 2006; Erwin \& Thacker, 2007; Maldonado, Ribes \& van Duyl, 2012; 469 Gloeckner et al., 2014). The horizontal black line represents the cutoff above which sponges are 470 considered to have high chl $a\left(>125 \mu \mathrm{g}\right.$ of chl $a$ [g of sponge tissue ${ }^{-1}$; Erwin \& Thacker, 2007). 471 Abbreviations represent the first letter of the genus name, followed by the first three letters of the 472 specific epithet.

473 Figure 2: Bivariate $\delta^{13} \mathrm{C}$ and $\delta^{15} \mathrm{~N}$ plot depicting the placement of HMA and LMA (a) and HMA 474 sponges with high and low chl $a$ concentrations (HMA-H and HMA-L, respectively) and LMA 475 groups (b) within the isotopic niche space of the Miskito Cays. Standard ellipse areas (SEA $)$ 476 depicted by solid lines provide estimates of the niche area of each of these groups using Bayesian 477 inference as in Jackson et al. (2011). Convex hulls depicting total niche width of each group are 478 shown using dashed lines for reference (Layman et al., 2007a).

479 Figure 3: Bivariate $\delta^{13} \mathrm{C}$ and $\delta^{15} \mathrm{~N}$ plot depicting the placement of HMA and LMA sponges within 480 the isotopic niche space of Media Luna Site \#2 (a) and Media Luna Site \#3 (b). In addition, (c) 481 depicts the placement of HMA sponges with high and low chl $a$ concentrations (HMA-H and 482 HMA-L, respectively) and LMA groups within the isotopic niche space of Media Luna Site \#3 483 (c). As in Figure 2, standard ellipse areas $\left(\mathrm{SEA}_{c}\right)$ are depicted by solid lines and convex hulls are 484 depicted using dashed lines for reference. Note the difference in the scale of the $\delta^{15} \mathrm{~N}$ axis 485 between $\mathrm{a}$ and $\mathrm{b}$ and $\mathrm{c}$.

486 Figure 4: Bivariate $\delta^{13} \mathrm{C}$ and $\delta^{15} \mathrm{~N}$ plot depicting the placement of 19 sponge species within the 487 isotopic niche space of the Miskito Cays. As in Figure 2, solid lines depict standard ellipse areas $488\left(\mathrm{SEA}_{\mathrm{c}}\right)$ and dashed lines depict convex hulls for reference. Species abbreviations are the same as 489 in Figure 1.

490 Figure 5: Bivariate $\delta^{13} \mathrm{C}$ and $\delta^{15} \mathrm{~N}$ plot depicting the placement of 12 species within the isotopic 491 niche space of Media Luna Site \#2 (a) and 11 species within the isotopic niche space of Media 492 Luna Site \#3 (b). As in Figure 2, standard ellipse areas $\left(\mathrm{SEA}_{\mathrm{c}}\right)$ are depicted by solid lines and 493 convex hulls are depicted using dashed lines for reference. Species abbreviations are the same as 494 in Figure 1. Note the difference in the scale of the $\delta^{15} \mathrm{~N}$ axis between a and $\mathrm{b}$. 


\section{1}

Mean Chlorophyll a ( $\mathrm{Chl}$ a) concentration ( $\pm \mathrm{SE}$ ) of 19 common sponge species collected within the Miskito Cays of Honduras.

Figure 1: Mean Chlorophyll a ( $\mathrm{Chl}$ a) concentration $( \pm \mathrm{SE}$ ) of 19 common sponge species collected within the Miskito Cays of Honduras. Sponges are categorized based on their overall microbial abundance into High Microbial Abundance (HMA) and Low Microbial Abundance (LMA) groups (Weisz, 2006; Erwin \& Thacker, 2007; Maldonado, Ribes \& van Duyl, 2012; Gloeckner et al., 2014). The horizontal black line represents the cutoff above which sponges are considered to have high chl a ( $>125 \mu \mathrm{g}$ of chl a [ $\mathrm{g}$ of sponge tissue ${ }^{-1}$; Erwin $\&$ Thacker, 2007). Abbreviations represent the first letter of the genus name, followed by the first three letters of the specific epithet.

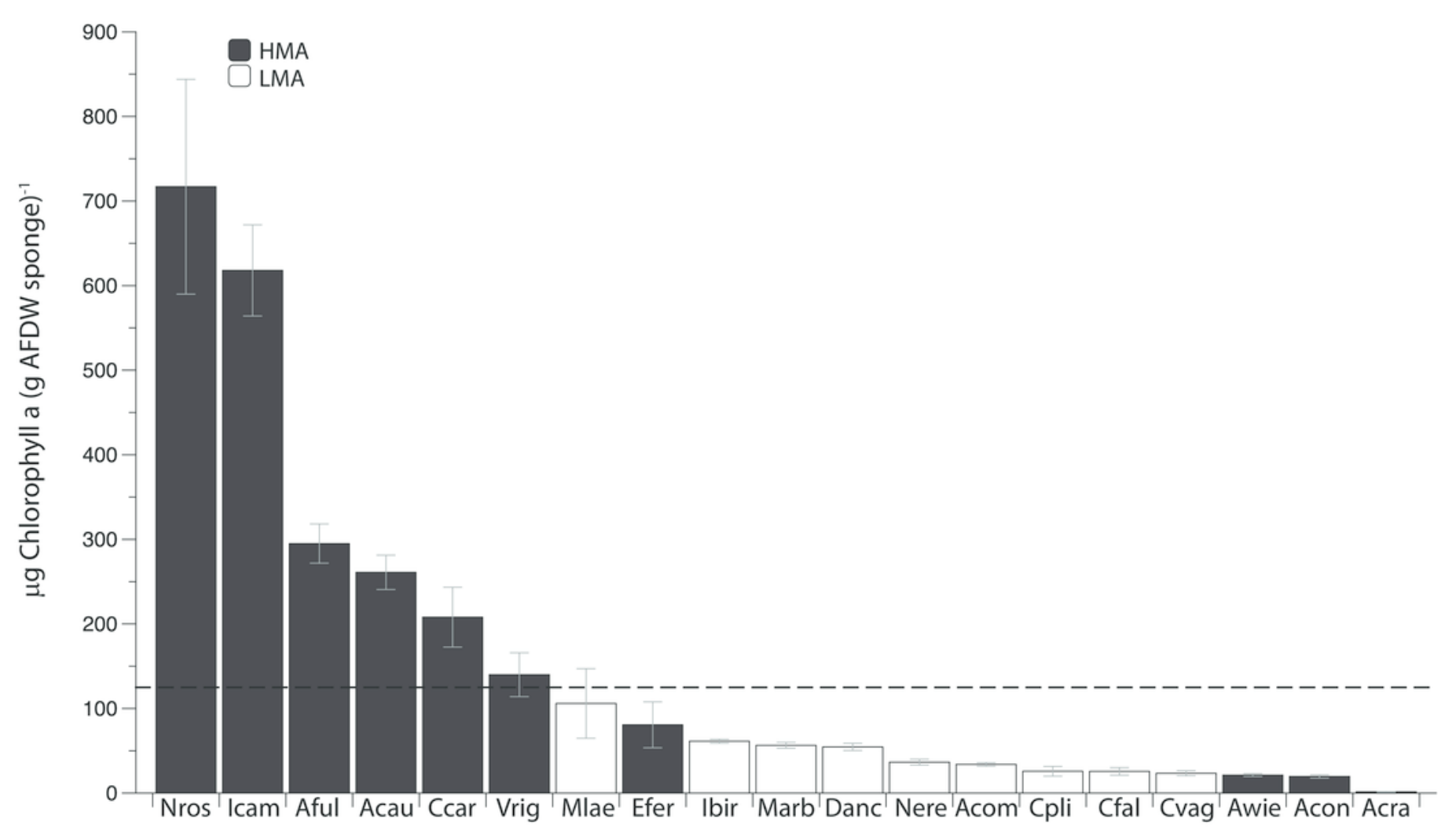




\section{2}

Bivariate $\delta^{13} \mathrm{C}$ and $\delta^{15} \mathrm{~N}$ plot depicting the placement of groups within the isotopic niche space of the Miskito Cays.

Figure 2: Bivariate $\delta^{13} \mathrm{C}$ and $\delta^{15} \mathrm{~N}$ plot depicting the placement of HMA and LMA (a) and HMA sponges with high and low chl a concentrations (HMA-H and HMA-L, respectively) and LMA groups (b) within the isotopic niche space of the Miskito Cays. Standard ellipse areas $\left(\mathrm{SEA}_{c}\right)$ depicted by solid lines provide estimates of the niche area of each of these groups using Bayesian inference as in Jackson et al. (2011). Convex hulls depicting total niche width of each group are shown using dashed lines for reference (Layman et al., 2007a). 

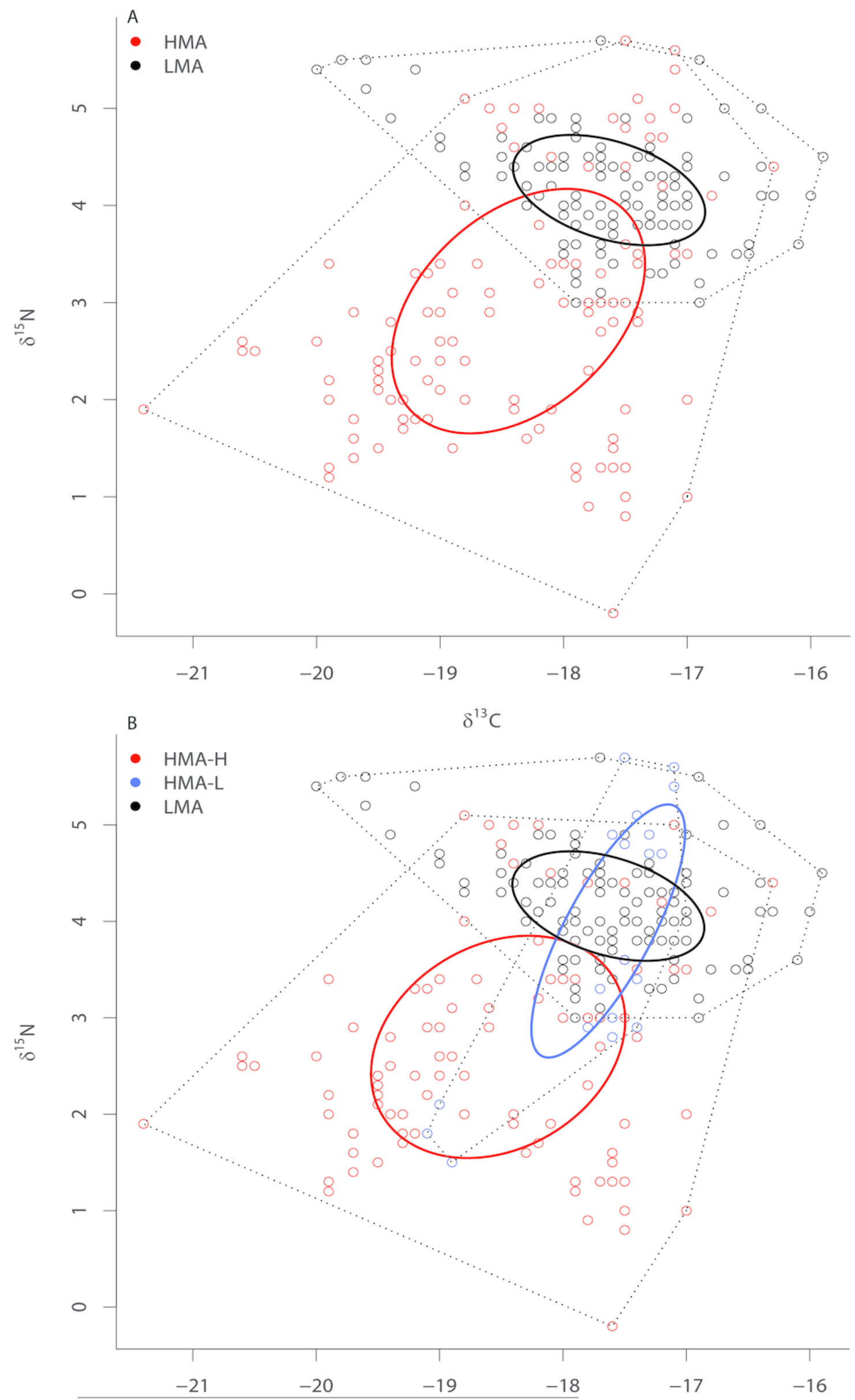

PeerJ reviewing PDF | (v2014:09:2786:1:0:ACCEPTED 21 Nov 2014)

$\delta^{13} \mathrm{C}$ 


\section{Table 1 (on next page)}

Table 2 source file

Table 2: Species of conspicuous sponges observed $(X)$ at 14 sites within the Miskito Cays of Honduras. 


\begin{tabular}{|c|c|c|c|c|c|c|c|c|c|c|c|c|c|}
\hline $\begin{array}{l}\text { Agelas conifera (Schmidt, } \\
\text { 1870) }\end{array}$ & & & & & & & & & & & $\mathrm{X}$ & $X$ & $\mathrm{X}$ \\
\hline $\begin{array}{l}\text { Agelas wiedenmayeri } \\
\text { Alcolado, } 1984\end{array}$ & $\mathrm{X}$ & & $\mathrm{X}$ & & & & & & & & & & \\
\hline $\begin{array}{l}\text { Aiolochroia crassa (Hyatt, } \\
\text { 1875) }\end{array}$ & & & & & & & & & & & $\mathrm{X}$ & $\mathrm{X}$ & $\mathrm{X}$ \\
\hline $\begin{array}{l}\text { Siphonodictyon } \\
\text { coralliphagum Rützler, } 1971\end{array}$ & & & & & & & & & & & $\mathrm{X}$ & & \\
\hline $\begin{array}{l}\text { Amphimedon compressa } \\
\text { Duchassaing \& Michelotti, } \\
1864\end{array}$ & & & $\mathrm{X}$ & & $\mathrm{X}$ & & & & & $\mathrm{X}$ & $\mathrm{X}$ & $\mathrm{X}$ & $\mathrm{X}$ \\
\hline $\begin{array}{l}\text { Aplysina cauliformis (Carter, } \\
\text { 1882) }\end{array}$ & & $X$ & & $X$ & $X$ & $X$ & & & & $\mathrm{X}$ & $X$ & $X$ & $X$ \\
\hline $\begin{array}{l}\text { Aplysina fulva (Pallas, } \\
1766 \text { ) }\end{array}$ & & $\mathrm{X}$ & & & $\mathrm{X}$ & $\mathrm{X}$ & & & & $\mathrm{X} \mid$ & $\mathrm{X}$ & $X$ & $\mathrm{X}$ \\
\hline $\begin{array}{l}\text { Aplysina lacunosa } \\
\text { (Lamarck, 1814) }\end{array}$ & & & & & & & & & & & $\mathrm{X}$ & $\mathrm{X}$ & $\mathrm{X}$ \\
\hline $\begin{array}{l}\text { Callyspongia (Callyspongia) } \\
\text { fallax Duchassaing \& } \\
\text { Michelotti, } 1864\end{array}$ & & & & $\mathrm{X}$ & $\mathrm{X}$ & & & & & & $\mathrm{X}$ & $X$ & $X$ \\
\hline $\begin{array}{l}\text { Callyspongia (Cladochalina) } \\
\text { plicifera (Lamarck, 1814) }\end{array}$ & & & & & $X$ & & & & & & $X$ & $X$ & $X$ \\
\hline $\begin{array}{l}\text { Callyspongia (Cladochalina) } \\
\text { vaginalis (Lamarck, 1814) }\end{array}$ & & $X$ & & & $X$ & & & & & $\mathrm{X}$ & $X$ & $X$ & $X$ \\
\hline $\begin{array}{l}\text { Chondrilla caribensis } \\
\text { Rützler, Duran, \& Piantoni, } \\
2007\end{array}$ & & & & & & & & & & & $\mathrm{X}$ & $X$ & $X$ \\
\hline Cliona delitrix Pang, 1973 & & & & & & & & & & & $\mathrm{X}$ & $\mathrm{X}$ & \\
\hline $\begin{array}{l}\text { Desmapsamma anchorata } \\
\text { (Carter, 1882) }\end{array}$ & & & & & & & & & & & & $\mathrm{X}$ & $\mathrm{X}$ \\
\hline $\begin{array}{l}\text { Ectyoplasia ferox } \\
\text { (Duchassaing \& Michelotti, } \\
\text { 1864) }\end{array}$ & & & & & & & & & & & & $\mathrm{X}$ & \\
\hline $\begin{array}{l}\text { lotrochota birotulata } \\
\text { (Higgin, 1877) }\end{array}$ & & $X$ & & $\mathrm{X}$ & $\mathrm{X}$ & $X$ & & & & & $X$ & $X$ & $X$ \\
\hline $\begin{array}{l}\text { Ircinia campana (Lamarck, } \\
\text { 1814) }\end{array}$ & & & & $\mathrm{X}$ & $X$ & & & & & & $X$ & $X$ & $X$ \\
\hline $\begin{array}{l}\text { Ircinia felix (Duchassaing \& } \\
\text { Michelotti, 1864) }\end{array}$ & $\mathrm{X}$ & & & & & & & & & & $X$ & $X$ & $\mathrm{X}$ \\
\hline $\begin{array}{l}\text { Ircinia strobilina (Lamarck, } \\
\text { 1816) }\end{array}$ & & & & & & & & & & & $\mathrm{X}$ & & $X$ \\
\hline $\begin{array}{l}\text { Monanchora arbuscula } \\
\text { (Duchassaing \& Michelotti, } \\
\text { 1864) }\end{array}$ & & & & & & & & & & & $\mathrm{X}$ & $\mathrm{X}$ & $\mathrm{X}$ \\
\hline
\end{tabular}




\begin{tabular}{|l|l|l|l|l|l|l|l|l|l|l|l|l|l|l|}
\hline $\begin{array}{l}\text { Mycale (Mycale) laevis } \\
\text { (Carter, 1882) }\end{array}$ & & & & & & & & & & & & X & X & X \\
\hline $\begin{array}{l}\text { Neopetrosia rosariensis } \\
\text { (Zea \& Rützler, 1983) }\end{array}$ & X & & & X & & & & & & & & & & \\
\hline $\begin{array}{l}\text { Neopetrosia subtriangularis } \\
\text { (Duchassaing, 1850) }\end{array}$ & & & & & & & & & & & & & & X \\
\hline $\begin{array}{l}\text { Niphates erecta } \\
\text { (Duchassaing \& Michelotti, } \\
\text { 1864) }\end{array}$ & & X & X & & X & & & & & & & X & X & X \\
\hline $\begin{array}{l}\text { Verongula rigida (Esper, } \\
\text { 1794) }\end{array}$ & X & X & X & & X & X & & & & & X & X & X & X \\
\hline
\end{tabular}

Table 2: Species of conspicuous sponges observed (X) at 14 sites within the Miskito Cays of Honduras. 


\section{3}

Bivariate $\delta^{13} \mathrm{C}$ and $\delta^{15} \mathrm{~N}$ plot depicting the placement of groups within the isotopic niche space of two sites.

Figure 3: Bivariate $\delta^{13} \mathrm{C}$ and $\delta^{15} \mathrm{~N}$ plot depicting the placement of HMA and LMA sponges within the isotopic niche space of Media Luna Site \#2 (a) and Media Luna Site \#3 (b). In addition, (c) depicts the placement of HMA sponges with high and low chl a concentrations (HMA-H and HMA-L, respectively) and LMA groups within the isotopic niche space of Media Luna Site \#3 (c). As in Figure 2, standard ellipse areas $\left(\mathrm{SEA}_{c}\right)$ are depicted by solid lines and convex hulls are depicted using dashed lines for reference. Note the difference in the scale of the $\delta^{15} \mathrm{~N}$ axis between $\mathrm{a}$ and $\mathrm{b}$ and $\mathrm{c}$. 

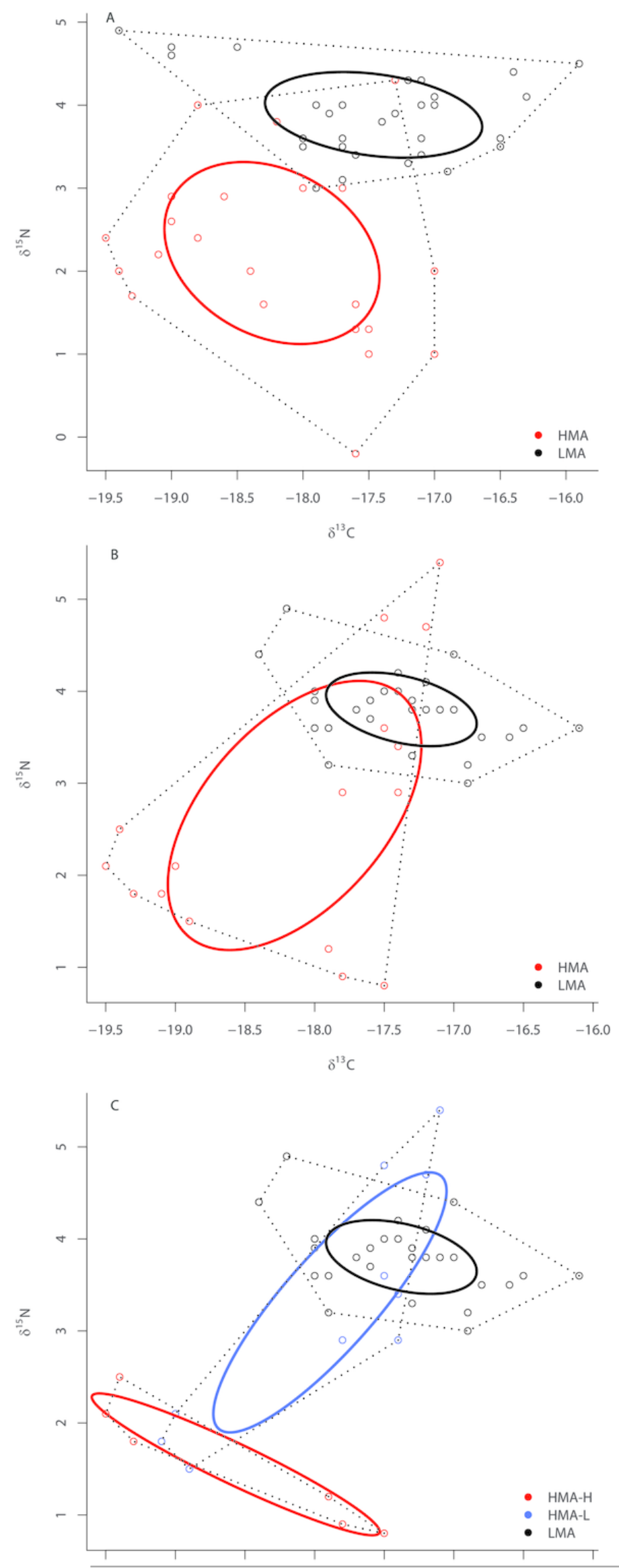

PeerJ reviewing PQF | (v2014:09:27:86:1:0:ACCEPTEED 21-Noov 2014) 


\section{4}

Bivariate $\delta^{13} \mathrm{C}$ and $\delta^{15} \mathrm{~N}$ plot depicting the placement of 19 sponge species within the isotopic niche space of the Miskito Cays.

Figure 4: Bivariate $\delta^{13} \mathrm{C}$ and $\delta^{15} \mathrm{~N}$ plot depicting the placement of 19 sponge species within the isotopic niche space of the Miskito Cays. As in Figure 2, solid lines depict standard ellipse areas $\left(\mathrm{SEA}_{c}\right)$ and dashed lines depict convex hulls for reference. Species abbreviations are the same as in Figure 1.

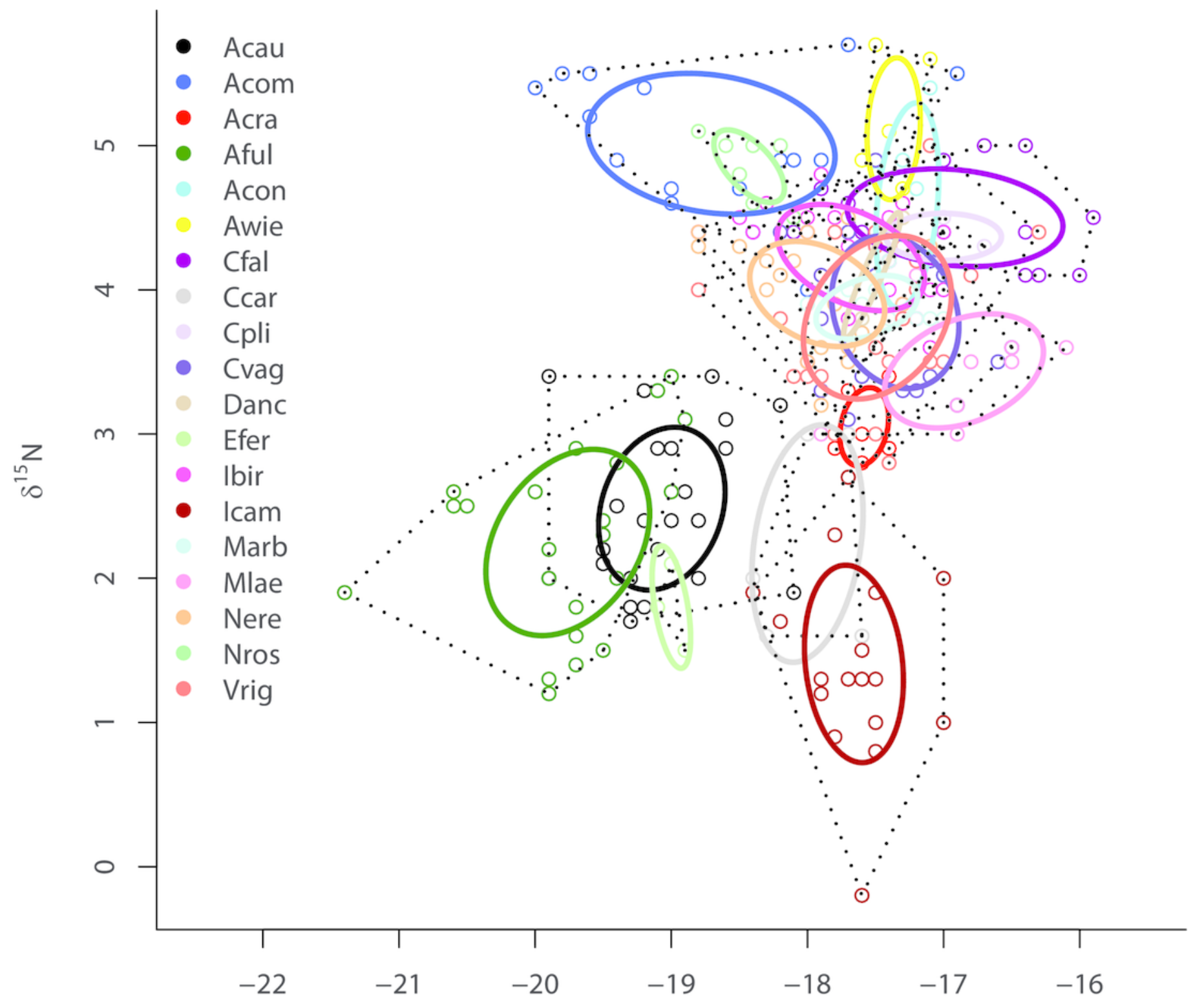




\section{5}

Bivariate $\delta^{13} \mathrm{C}$ and $\delta^{15} \mathrm{~N}$ plot depicting the placement of species within the isotopic niche space of two sites.

Figure 5: Bivariate ${ }^{13} \mathrm{C}$ and $\delta^{15} \mathrm{~N}$ plot depicting the placement of 12 species within the isotopic niche space of Media Luna Site \#2 (a) and 11 species within the isotopic niche space of Media Luna Site \#3 (b). As in Figure 2, standard ellipse areas $\left(S_{E} A_{c}\right)$ are depicted by solid lines and convex hulls are depicted using dashed lines for reference. Species abbreviations are the same as in Figure 1. Note the difference in the scale of the $d^{15} \mathrm{~N}$ axis between $a$ and $b$. 

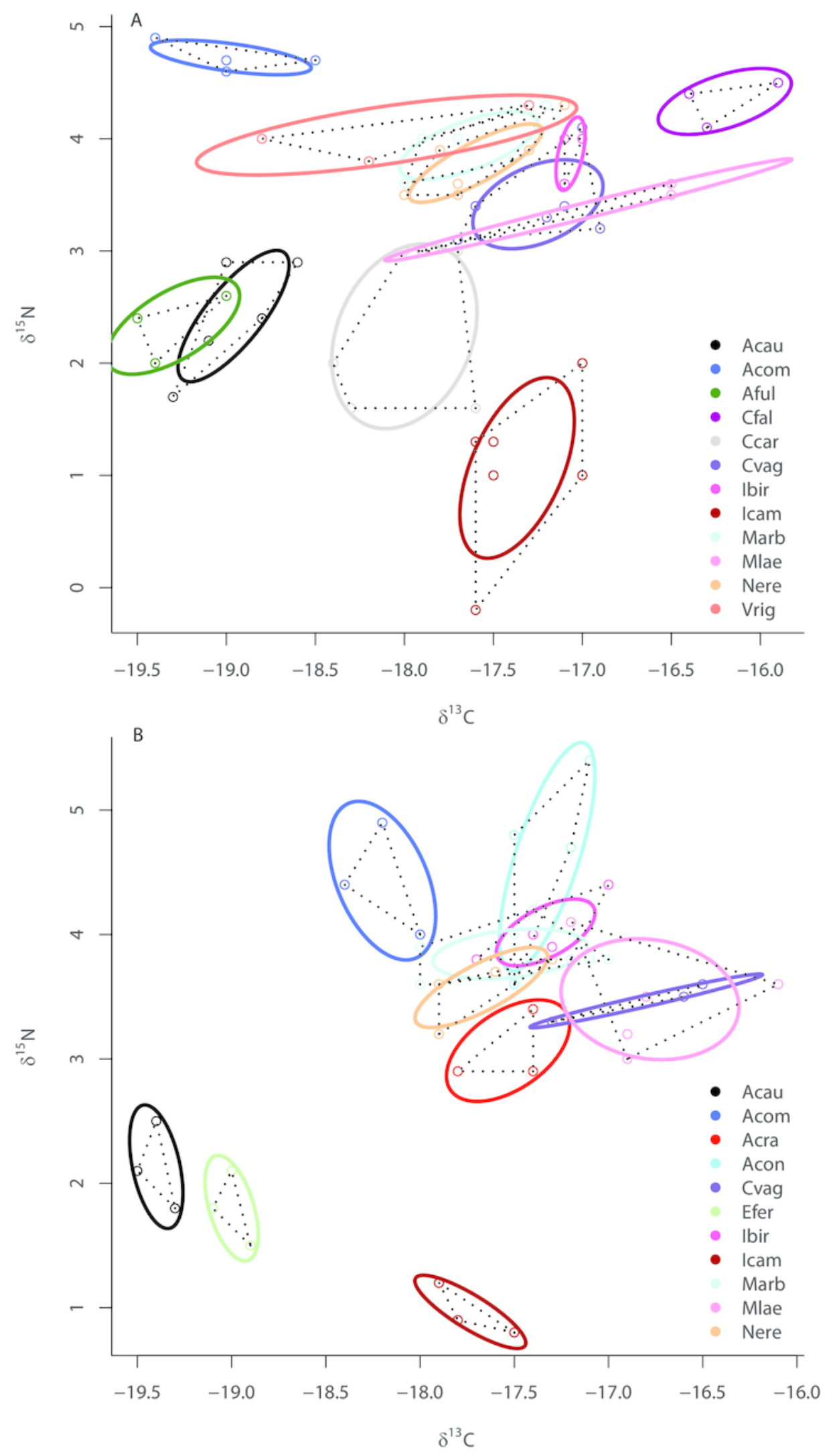
Table 2 (on next page)

Names and GPS coordinates of 14 sites visited within the Miskito Cays of Honduras.

Table 1: Names and GPS coordinates of 14 sites visited within the Miskito Cays of Honduras. 
Table 1: Names and GPS coordinates of 14 sites visited within the Miskito Cays of Honduras.

\begin{tabular}{lcc}
\hline \multicolumn{1}{c}{ Site } & Latitude-N & Longitude-W \\
\hline Vivorillos Site \# 1 & 15.837 & -83.291 \\
Vivorillos Site \# 2 & 15.863 & -83.306 \\
Becerros Site \# 1 & 15.913 & -83.255 \\
Becerros Site \# 2 & 15.951 & -83.272 \\
Caratasca Site \# 1 & 16.024 & -83.316 \\
\hline Caratasca Site \# 2 & 16.030 & -83.319 \\
Cajones Site \# 1 & 16.033 & -83.094 \\
Cajones Site \# 2 & 16.057 & -83.100 \\
Cajones Site \# 3 & 16.085 & -83.143 \\
Cajones Site \# 4 & 16.093 & -83.173 \\
Media Luna Site \# 1 & 15.261 & -82.631 \\
Media Luna Site \# 2 & 15.186 & -82.618 \\
Media Luna Site \# 3 & 15.139 & -82.582 \\
Media Luna Site \# 4 & 15.122 & -82.587 \\
\hline
\end{tabular}

